\title{
AJAST JA ARUST EHK TEMPUSEST JA TEADVUSEST EESTI KOMPLEMENTLAUSES
}

\author{
MÄRT VÄLJATAGA
}

$\mathrm{F}$ iloloogia kitsamas mõttes tähendab vanade tekstide toimetamist, seletamist ja algse kuju taastamist. Pretensioonikamas tähenduses, mille see sõna sai XVIII sajandil Giambattista Vicolt, on filoloogia aga enam-vähem seesama mis mõttelugu. Erich Auerbach võtab vicoliku arusaama kokku nõnda: „Teadust, mis püüab dokumente tõlgendades kindlaks teha, mida need tõeks on pidanud, nimetatakse filoloogiaks. Säärane laiem filoloogia hõlmab kõike, mida Saksamaal nimetatakse vaimulooks" (Auerbach 1965 [1958]: 15). Oma kõrgajal, XIX sajandil lähtus filoloogia eeldusest, et igal rahval on ainulaadne ja kordumatu vaim, mille tõekspidamised avalduvad keeles. Rahva keel kehastub aga kõige esinduslikumal kujul luuleloomingus. Kirjanduskeele uurimine aitab meid seega lähemale rahva vaimu tundmaõppimisele ja see omakorda on eeldus kõige muu mõistmiseks.

Esimese tähenduse äärmus seostab filoloogia paberkuiva pedantsusega, mis nüüdisajal avaldub vist pigem üldistusi pelgavas lingvistilises nokitsemises. Teine tähendus seostub lahmiva lennukusega, mida kohtab kirjandustõlgendustes. Muidugi leidub pedante ja spekulante nii ühel kui ka teisel pool. Kui aga filoloogia aluseks olnud mõttekäiku keele, luule ja rahvavaimu seostest puhta kullana võtta, peaks küsima, millised kogemis- ja mõtlemismustrid on talletunud eesti kirjanduskeelde ja kas selle arengu vaatlemine annaks alust ka lennukamatele järeldustele. Keele vorminähtustest sisu või tähenduse väljameelitamist nimetatakse sageli ka stilistikaks.

Käesolev, mitmeosalisena mõeldud käsitlus üritab sellises filoloogilises vaimus uurida üht eesti grammatika ja stiili joont, olevikuaja kasutamist minevikulises kontekstis, ning vaadelda selle siirdeid jutukirjandusse. Alustades õige kaugelt, komplementlausete grammatikast, peatudes järgmistes osades ajakasutusel siirdkõnes ning olevikulise jutustamise eripäradel ja kohal kirjandusloos, tahaksin lõpuks jõuda ühe konkreetse juhtumi, A. H. Tammsaare „Kõrboja peremehe” ajasuhete vaatluseni.

\section{Komplementlause aeg ja orientatsioonikese}

Käesolev artikkel uurib seda, millest sõltub eesti keeles minevikulisele pealausele alistatud komplementlause tempus, kui komplementlause kujutab pealause verbiga samaaegset sündmust. Miks esineb sel juhul mõnda tüüpi komplementlauses alati olevik, mõnes tüübis alati minevik ja mõnes tüübis kord minevik, kord olevik? Küsimusele vastuse leidmiseks lähtun mõnest 
Adrian Barentseni (1996) oletusest, mida kontrollin eesti etTenTen’i korpuse, ${ }^{1}$ guugeldamisel leitud näidete ja kirjandustekstide põhjal.

Eesti keeles on kaks aega: olevik ehk preesens ja minevik ehk preteeritum. Olevik märgib igasugust mitteminevikulist sündmust ja on ühtlasi nn üldaeg. Minevik võib väljenduda lihtmineviku ehk imperfektina, täismineviku ehk perfektina ja ennemineviku ehk pluskvamperfektina. Täis- ja enneminevik, mida siinses käsitluses nimetatakse perfektiaegadeks, väljendavad kaheplaanilist ajatähendust, mis on seotud vastavalt olevikulise või minevikulise vaatlushetkega.

Traditsioonilistes grammatikates piiritletakse veel spetsiifilisemaid oleviku tähendusi. Näiteks Boriss Serebrennikov refereerib Aarni Penttilä jaotust (näited minult): I. aktuaalne olevik (Kas hammas valutab?), mille erijuhtudena tuuakse välja: 1) habituaalne olevik (Kas te suitsetate?), 2) liialduste olevik (Kui mul õigus on, miks sa siis mind lööd!), 3) annaalide olevik ja ajalooline olevik (Kirjad, mis Koidula Kroonlinnast tuttavatele ja omastele läkitab, nõretavad pisaraist), 4) referaadi või sünopsise olevik (Josh valab viha Andy peale. Irene läheb Gregiga kohtama. Kat kahtlustab, et Nate'i ja Ricky vahel on midagi teoksil) ning 4) auktoriaalne olevik (Paulus ütleb kirjas korintlastele...); II. olevik tuleviku tähenduses (Homme sööme komme); III. neutraalne ehk ajatu olevik (Kaks pluss kaks on neli) (Serebrennikov 1963: 445-446).

Meie keelele pole iseloomulik mitmes keeles tuntud grammatikanähtus, consecutio temporum, aegade ühildumine. Aegade ühildumisega keeltes teisendab pealause aja minevikku nihutamine ka kõrvallause aega. Eriti selgelt avaldub see kaudkõnes, nt inglise, soome, rootsi, prantsuse jpt keeltes:

(1) John said: „I am ill.” $\rightarrow$ John said that he was ill. ${ }^{2}$

Seevastu eesti keeles, sarnaselt vene, tšehhi, ungari, rumeenia jpt keeltega, sellist nihet ei toimu: kaudkõne pealause aeg ei avalda kõrvallause ehk referaadi ajale mõju. Kõrvallauses kasutatakse absoluutse asemel relatiivset aega:

(2) Jaan ütles: „Olen haige.” $\rightarrow$ Jaan ütles, et on haige.

Lisaks on keeli (saksa, läti), kus ütluse otsekõnest ülekandmisel kaudkõnne muutub pigem kõrvallause kõneviis, kas ühes ajaga või mitte.

Kaudkõne istutab ühe isiku ütlused teise (või ka sellesama) isiku kõne konteksti. Otsekõnest ehk tsitaadist kaudkõne moodustamise üksikasjalikumaid reegleid pole eesti keele jaoks formuleerida riskitud, sest päris palju jääb siin konteksti hoolde. Lisaks jutumärkide kõrvaldamisele ja sidendi et lisamisele tuleks kaudkõnes kustutada otsekõne ekspressiivsus ja subjektiivsus ning arusaadavuse huvides teisendada ka isikulisi asesõnu ja deiktikuid. Sageli jäetakse need ka teisendamata, ilma et suuremat kahju sünniks:

${ }^{1}$ etTenTen korpus (http://www2.keeleveeb.ee/dict/corpus/ettenten) on internetist alla laetud eestikeelsete veebilehtede korpus. Korpuses on 270 miljonit sõna 686000 veebilehelt.

${ }^{2}$ Siin ja edaspidistes on näidetes relevantne pealauseverb alla joonitud ja kõrvallause verb kursiivis. 
(3) Võib-olla ei mõtleks ta siis enam millelegi, ei kõhkleks silmapilgukski, võtaks koha paberid, sõidaks linna ja ütleks tütrele, et kui tahad, lähme nüüd notari juurde, sest minul on Kõrboja peremehe ametist himu otsas ja mina tahaksin ta kõigega tükkis sinu kätte anda. (A. H. Tammsaare, Kõrboja peremees. [E-raamat.] Tartu: Linnaraamatukogu, 2012, 4. ptk)

(4) Mina küsisin: mis s a siin teed? Tema ütles, et käisin niisama poe juures vaatamas. Mina küsisin siis, mis pudruga sa oma habeme ja mokad oled kokku määrinud, tema ütles, mis pudruga, ma ostsin pool naela halvaad vaat siis oli haridus juba maale tulnud. (Jaanus Andreus Nooremb [Madis Kõiv ja Hando Runnel], Küüni täitmine. Looming 1978, nr 4, lk 620)

(5) Siis ta läheb kohe oma ametiühingu esimehe juurde, ütleb, et Järvi ütles, et ma ei ole piisavalt hea, ja ametiühing hakkab teda kaitsma. (Neeme Järvi, Encore! Neeme Järvi. Tallinn: SE \& JS, 2001, lk 40)

(6) Ei ütelnud ju seltsimees Stalin, et homsest algab minu kultuse periood. Ei öelnud ka Nikita Sergejevitš Hruštšov, et nüüd tuleb mind kui ustavat leninlast aupresiidiumidesse valida. (Jüri Paalma, Miks ma venelasi ei armasta? Noorus 1987, nr 11, lk 13)

Kas lugeda ka need laused (ja näide 75 allpool), milles otsekõne asesõnad ja ekspressiivsus on alles jäänud, kaudkõne juhtude hulka, pidada neid keelevigadeks või käsitleda mingi omaette liigituse all, nagu kvaasi- või pseudootsekõne - see on suurel määral keelekorralduse ja taksonoomiate koostamise küsimus. Igal juhul on otsekõne ja puhta kaudkõne vahel lai kirev ala, mis eesti ja vene keeles on arvatavasti laiem ja kirevam kui „grammatilisemas” inglise ja prantsuse keeles.

Kui aga sõnade ümberseadmisel kaudkõnne teisendatakse ka aega, võib sündida juba suuremat semantilist kahju. Kehv tõlge on kaugelt äratuntav kaudkõnne sobimatu mineviku järgi:

(7) Mary told me that I was beautiful.

(8) Mary ütles mulle, et olin kaunis.

Erinevalt ingliskeelsest (7) annab Mary eesti lause (8) mõista, nagu oleks minu (kui terviklause esitaja) ilu juba minevikku vajunud.

Kaudkõne liigiks võib arvata ka kaudsisekõne (Mari ütles endamisi, et Jüri on kaunis) ja „kaudmõtte” (Mari mõtles, et Jüri on kaunis). „Kaudmõte” läheb sujuvalt üle „kaudtundeks” (Jüri tundis, et Mari on kaunis) ning mõlemaga seostub „kaudtaju”: Jüri nägi, et Mari on / oli kaunis. Skaala ühes otsas on pealauseisiku tuvastatavate sõnade esitus, kusagile keskele jäävad tema enam-vähem sõnastatud privaatsed tõdemused ning teise otsa vaimusündmused, millega kogejas mingit verbaalset ekvivalenti kaasneda ei tarvitse ja millele annab sõnastuse hoopis terviklause kõneleja ehk jutustaja. ${ }^{3} \mathrm{Me}$ ju ei taju maailmasündmusi ja -asju neid kogu aeg otsekui verbaalsete subtiitritega varustades.

${ }^{3}$ Natuke sellesarnaseid kõne- ja mõtteedastuse skaalasid on esitanud Brian McHale (1978: 258-261) ning Geoffrey Leech ja Michael Short (1981: 324). 


\section{Tõlkeprobleemid}

Järjekindla consecutio temporum'iga keelte ning ebajärjekindla või haruldase consecutio temporum'iga keelte erinevus seab tõlkija ette ühe raskuse - ja mitte üksnes kaudkõne või muude kõnereferaatide, vaid ka tajulausete tõlkimisel. Tuleb otsustada, kus jätta minevikulise jutustuse kontekstis alles kõrvallause absoluutne aeg (aeg kõne- või jutustamishetke seisukohalt ehk antud juhul minevik) ja kus kasutada relatiivset aega (aega mingisuguse kontekstilise hetke seisukohalt ehk antud juhul olevikku). Mõned näited tõlkeist, kus preteeritumis kõrvallause tõlkimisel on otsustatud preesensi kasuks:

(9) „I hope so,” I answered, and turned to go back to the camp, when I saw that we were not alone. (H. R. Haggard, King Solomon's Mines, 5. ptk. http:// www.gutenberg.org/files/2166/2166-h/2166-h.htm)

(10) „Minagi loodan seda,” vastasin ja pöördusin ümber, et laagrisse tagasi minna, kui äkki märkasin, et me pole üksi. (H. R. Haggard, Kuningas Saalomoni kaevandused. Tlk Lia Rajandi. Tallinn: Eesti Riiklik Kirjastus, 1960, lk 48)

(11) Then, creeping closer, I saw that he was not dead, but sleeping soundly, with Foulata's taper fingers clasped tightly in his poor white hand. (H. R. Haggard, King Solomon's Mines, 15. ptk)

(12) Lähemale hiilides nägin, et ta pole surnud, vaid magab sügavasti, pigistades kramplikult oma vaeses valges peos Foulata saledaid sõrmi. (H. R. Haggard, Kuningas Saalomoni kaevandused, lk 170)

(13) Pooh was very proud when he heard this, and he felt that the Heffalump was as good as caught already... (A. A. Milne, Winnie-the-Pooh, ptk 5)

(14) Puhh oli kangesti uhke, kui ta seda kuulis, ja talle näis, et see Elevants on neil juba niisama hästi kui käes. (A. A. Milne, Karupoeg Puhh. Tlk Valter Rummel. Tallinn: Eesti Raamat, 1968, lk 48)

Valma Yli-Vakkuri (1994) on oma töögrupiga eesti-soome kontrastiivuuringute raames vaadelnud, kuidas Mati Undi „Sügisballi” jt kirjanike soome tõlkes on kõrvallause olevik nihkunud minevikku ja soome kirjanike eesti tõlgetes minevik olevikku.

(15) Mul oli eile niikuinii väga kurb ja tühi õhtu, ütles ta, pidas pausi ja oli kuulda, et ta otsib suitsu ja paneb selle siis põlema.... (Mati Unt, Sügisball, vt Yli-Vakkuri 1994: 146)

(16) Minun iltani on ollut mahdottoman tylsä ja tyhjä, hän sanoi, piti sitten tauon ja kuului miten hän etsi tupakkaa ja sytytti sen.... (Mati Unt, Syystanssi, tlk Eeva Lille, vt Yli-Vakkuri 1994: 146)

(17) Seimi tuli sisään. Hän kertoi, että jossain oli varmasti iso metsäpalo. (Veikko Huovinen, Havukka-ahon ajattelija, vt Yli-Vakkuri 1994: 141)

(18) Anselmi tuli sisse. Ta rääkis, et kuskil on kindlasti suur metsapõlemine. (Veikko Huvoinen, Havukka-aho mõtleja, tlk Harald Leppik, vt YliVakkuri 1994: 141) 
Kui minevikulise pealause kõrvallauses kasutatakse üldoleviku asemel minevikku, siis on haista tõlkehalbust. Tundub, et soome keelest tõlkimisel tehakse seda viga isegi rohkem kui inglise või prantsuse keelest:

(19) Kolumbus arvas, et maa oli märgatavalt väiksem, kui see tegelikult on, mistõttu pidas ta lääne mereteed Indiasse hõlpsasti ja kiiresti leitavaks. (http://www.areiopagi.fi/lameda-maa-muut-keskaja-kirik-teadis-et-maaon-ummargune-vahemalt-700-aastat-enne-kolumbust) ${ }^{4}$

\section{Komplementlause}

Süntaktilise liigenduse poolest moodustavad kaudkõnelaused osakese ühest suuremast liitlauseliigist, komplementlausega põimlausetest. Seda liiki lausetes toimib kõrvallause pealause suhtes aluse või sihitisena, harvemini öeldistäite või määrusena, ning laiendab harilikult psühho- või suhtlussõnu (EKG II: 282; Erelt 2014: 40). ${ }^{5}$

Allpool on valik „Eesti keele grammatika” komplementlausete näidetest (EKG II: 282-287), kus pealause on minevikus ja kõrvallause olevikus või täisminevikus. Valitud on ainult laused, kus kõrvallause sündmus on tõlgendatav pealause sündmusega samaaegsena. Tõsi, mõnel puhul võidakse kõrvallauses mainida ka mingit ajatut olukorda (näide 20 ) või sündmust, mis kestab veel pealause kõnehetkel ja kauemgi (näited 22, 23, 25, 30 jt).

(20) Ta koges omal nahal, et tööl on peale palga muidki väärtusi.

(21) Avastasin, et märkamatult on saabunud kevad.

(22) Ta oli tähele pannud, et Peeter värvib vuntse.

(23) Ta uuris välja, et Juhan käib Miinaga.

(24) Mul oli meeles, et Rein elab kolmandal korrusel.

(25) Järeldus oli selline, et plaani tuleb korrigeerida.

(26) Näis, et tal on midagi tähtsat öelda.

(27) Mul oli tunne, et me ei vaata elavat inimest, vaid suure meistri voolitud kuju.

(28) Jüri ütles, et Peeter on haige.

(29) Vanematele teatati, et nende poeg käitub halvasti.

(30) Isa seletas, et praegune aeg nõuab haridust.

(31) Ajakirjanik kirjutas, et Linda on eesrindlik lüpsja.

Pealausetes esindatud tegusõnade hulgas on lisaks kaudkõnet saatvatele ütlemisverbidele (verba dicendi, 28-31) ka taju-, tunnetus- ja mõtlemisverbe (verba sentiendi, cognoscendi et sciendi).

Kuid mõnes minevikulise pealausega näitelauses on minevikus ka kõrvallause, ehkki peaaegu igal pool oleks mõeldav ka olevik:

(32) Kõik nägid, et ta oli väsimusest kokku vajumas.

\footnotetext{
${ }^{4}$ Samas ollakse harjunud lausega „Ja jumal nägi, et see hea oli”, kuigi järele mõeldes peaks siingi kõrvallause olema pigem olevikus.

${ }^{5}$ Vene grammatikates nimetatakse niisuguseid kõrvallauseid selgitavateks (изъяснительные придаточные предложения).
} 
(33) Talle sai selgeks, et tema olukord oli lootusetu.

(34) Et lahendus oli ebaõige, jäi tähele panemata.

(35) Ta veendus, et isal oli õigus.

(36) Mulle tundus, et keegi karjatas.

(37) Juhan häbenes, et tal raha polnud.

(38) Seda, et nad enam ei kohtunud, pandi väga imeks.

(39) Rõõm selle üle, et teda kiideti, oli nii suur, et kiskus suu vägisi naerule.

Sealsamas leidub näitelauseid, kus kõrvallause kuulub „eksistentsiaalset” tüüpi sõnade juurde (EKG II: 287), ja seal näib minevik ainuvõimalik:

(40) See oli juhus, et nad ellu jäid.

(41) Juhtus, et haige suri.

Nendesarnaseid saab hõlpsasti juurde leida:

(42) Olukord oli kujunenud selliseks, et Jüri nuttis iga päev.

(43) See, et Jüri nuttis, oli midagi täiesti tavatut.

(44) Ja sündis, et lapsuke suri.

Paljudes EKG II näitelausetes (kuid mitte kõigis) oleks sidend et asendatav sidendiga kuidas:

(45) Milvi kujutles, et ta on filmitäht.

(46) Perenaisele puutus kõrvu, et nende koer ulub.

(47) Tüdruk tajus, et keegi seisab tema selja taha.

(48) Talle viirastus, et keegi jälitab teda.

(49) Märkasin, et see küsimus tabas teda ootamatult.

(50) Talle kuuldus, et välisuks käis.

(51) Tüdruk tundis vastikust selle vastu, et mehed teda piirasid.

\section{Grammatikad}

Millega kõrvallause aja varieerumisi seletada? Grammatikad on enamasti lihtsalt möönnud minevikulise pealause korral mõlemat võimalust, nii absoluutset mineviku- kui ka relatiivset olevikutempust. Nii ütleb „Eesti keele grammatika":

Ajaorientatsioon iseseisvas lauses on põhimõtteliselt absoluutne, kõrvallauses ja sekundaartarindis relatiivne, pea- või põhilause tegevusajale orienteeruv.

Märkus. Selle poolest erineb eesti keel nt inglise keelest, kus nt komplementlauses võib olla absoluutne aeg. (EKG I: 75)

Pealause sündmusega samaaegset, hilisemat või ajaliselt piiritlemata sündmust väljendatakse kõrvallauses üldiselt verbi olevikuvormiga. $\mathrm{Nt}$ 
Ta kuuleb/kuulis/on kuulnud/oli kuulnud, et Ants käib Mallega. (EKG II: $293)^{6}$

Kohe seejärel tunnistatakse ka mineviku võimalust:

Kui pealauses on imperfekt või pluskvamperfekt, siis osutab kõrvallause sündmuse samaaegsusele pealause sündmusega ka kõrvallause öeldisverbi imperfektivorm.... Nt

Ta nägi/oli näinud, kui Ants tuli. (EKG II: 293)

Valter Tauli grammatika lõigus „Subjekt- ja objektlause tempus” öeldakse, et kui kõrvallause sündmus on pealause tegevusega samaaegne, siis kasutatakse kõrvallauses (lauselaiendis) olevikku: „PL tegevusega samaaegset... tegevust väljendatakse LL-s Vpr-ga" (Tauli 1980: 230). Kohe seejärel mööndakse ka vastupidist: kui liht- või enneminevikulise pealausega kõrvallause sündmus on pealause sündmusega samaaegne, siis võib kõrvallause olla ka lihtminevikus („Kui PL-s on Vimpf/plu, siis PL tegevusega samaaegset... tegevust väljendab LL-s ka Vimpf").

Vihje teatava seletuse poole pakub möödaminnes välja hoopis Wiedemann. Ta mainib, et eesti kaudkõne „kõrvallauses kasutatakse preesensit, olgugi et põhisõnaks olev verbum dicendi on preteeritumis”. Ja jätkab: „Selline aegade suhe kehtib aga veel mujalgi, ka seal, kus lause ei sõltu vahetult verbum dicendi'st, nt. lubas temale anda nī pal'ju, kui temale taŕwis läheb..., läksin õue wātama, kuida tema läheb.... Ka siin märgib lauses kasutatud preesens seda, et öeldu paikneb kõneleja ettekujutuses; kui aga öeldut väljendataks faktina, siis kasutataks ka eesti keeles preteeritumi: ... kui temale taŕwis läks [...], ... kuida tema läks [...]" (Wiedemann 2011 [1875]: 628-629; minu rõhutus $-M . V$.).

Arvatavasti peab Wiedemann siin „kõneleja” (das Redende) all silmas pigem kõnealust kogejat - mitte terviklause esitajat, vaid pealauses figureerivat isikut. (Teise näitelause puhul - läksin õue wátama, kuida tema läheb need kaks küll kattuvad.) Wiedemann annab niisiis mõista, et kui kõrvallause sündmus või tegevus toimub pealause subjekti teadvuses, siis kasutatakse kõrvallauses olevikku, kui aga tahetakse rõhutada, et tegu on objektiivse faktiga, siis minevikku. Niisiis toob Wiedemann oma käsitlusse perspektiivi, vaate- või orientatsioonipunkti teema, mis on võetud tõsisema lingvistilise uurimise alla alles viimase poole sajandi pragmaatikas.

Wiedemanni sissevaadet edasi arendades tuginen hollandi russisti Adrian Barentseni artiklile „Nihkuvad orientatsioonipunktid tänapäeva vene keeles: Tempuse valik „kaudtajus”" (1996). Aspektikategooria olemasolu ja perfektiaegade puudumise tõttu vene keeles ei saa Barentseni tulemusi üksüheselt eesti keelele üle kanda, aga tempust puudutavad tähelepanekud paistavad üldjoontes kattuvat. On ju mõlemal juhul tegemist keelega, kus consecutio temporum üldreeglina ei kehti.

${ }^{6}$ Vrd ka Erelt 2013: 95: „Kõrvallause sündmusaeg suhestub eesti keeles pealause sündmusajaga, mistõttu kõrvallauses väljendavad relatiivset aega kõik morfoloogilised ajavormid. Märkus. Selle poolest erineb eesti keel nt inglise keelest, kus nt refereerivas komplementlauses võib olla ka absoluutne aeg. [---] Teisiti öeldes, eesti keele refereerivas komplementlauses ei kehti ladina grammatikast tuntud aegade ühildumise (consecutio temporum) reegel." 
Ajavormide tähendust saab kirjeldada sündmusaja ja teatava „deiktilise keskme" (ehk nullpunkti) suhte kaudu. Tavaliselt on selleks keskmeks terviklause ütlemis- ehk kõnehetk, mille suhtes sündmus on kas varasem, samaaegne või hilisem (perfektiaegade puhul arvestatakse ka vaatlushetke). Olevikus lihtlauset Jüri nutab mõistetakse nii, et jutt käib ajaperioodist, mis on lause ütlemishetkega samaaegne või seda sisaldav. Kui see lause on aga kõrvallause funktsioonis (Mari ütles, et Jüri nutab), siis osutab see ajaperioodile, mis terviklause ütlemishetke tingimata ei sisalda, vaid eelneb sellele. Nii Jüri nutt kui ka Mari jutt jäävad terviklause kõnehetke suhtes minevikku. Ent oleviku tähendus samaaegsuse märkijana on olemas ka siin, seostudes nüüd Mari kõnehetkega, mitte aga kõnehetkega, mil Mari ütlemisest kõneldakse. Samaaegsussuhe ei seostu enam terviklause lausumisajaga. Mari ütlemisest räägitakse minevikus, sest see on terviklause ütlemisele (kõnehetkele) eelnenud sündmus. Mari jutu ja Jüri nutu samaaegsusseos määrab aga ära kõrvallause oleviku. Iseenesest ei ütle lause küll midagi nutmisaja ja terviklause ütlemishetke (ehk sündmushetke ja kõnehetke) ajasuhte kohta. Välistatud pole võimalus, et Jüri nutt jätkub veel ka terviklause esitamise ajal ning lauset saab jätkata näiteks sõnadega ..., ja ta nutab ikka veel. Aegade ühildumisega keeltes kuulub esmatähtsus terviklause kõnehetkele. Kuid neiski keeltes saab mõnikord kasutada kõrvallauses olevikuvormi rõhutamaks, et sündmus kestab terviklause kõnehetkel ikka veel edasi:

(52) Mary said that John cries quite often.

Verbi ajalist seost terviklause ütlemishetkega nimetatakse absoluutseks tempuseks. Relatiivne tempus esineb seal, kus deiktiliseks orientatsioonipunktiks on mõne muu sündmuse või tegevuse aeg. Relatiivse tempuse selgeim näide on kaudkõne (vt näiteid 28-31). Sel juhul on lause pooltel erinev orientatsioonipunkt. Pealause orientatsioonipunktiks (Barentseni terminoloogias keskseks orientatsioonipunktiks, 1996: 17) on selle ütlemishetk. Kõrvallause orientatsioonipunkt (Barentsenil sekundaarne orientatsioonipunkt) on aga määratud pealause sündmuse või tegevusega.

Niisiis, millal on eesti komplementlauses vajalik või lubatud absoluutne ja millal relatiivne tempus? Või sama küsimus teises sõnastuses: millal on määrav keskne orientatsioonipunkt terviklause kõnehetkel ja millal toimib pealause sündmus sekundaarse orientatsioonipunktina?

Leidub üks komplementlause tüüp, milles relatiivne tempus on välistatud. Sel juhul esinevad subjektlauses „eksistentsiaalset” tüüpi verbid: juhtuma, esinema, ette tulema, sündima, olema (EKG II: 287, vt näiteid 40-44). Sellele väikesele rühmale, kus absoluutne tempus näib kohustuslik, on täpselt vastandlik kaudkõne, kus (peaaegu) kohustuslik on relatiivne aeg. ${ }^{7}$ Nende kahe äärmuse vahel paikneb lauserühmi, milles esineb nii absoluutset kui ka relatiivset aega ehk milles preteeritumis pealause korral on kõrvallauses võimalik nii minevik kui ka olevik. Üht sellist rühma iseloomustab see, et pealauses on väljend, mis osutab tajumisele, tajuverb, nagu nägema, kuulma,

${ }^{7}$ Vrd komplementlauset „Thales arvas/mõtles/ütles, et kõik koosneb veest” ja sama väite esitust indirektaalse lihtlausena "Thalese järgi/meelest/sõnul/arvates/arust koosnes kõik veest”. 
tundma, märkama, kuulama, vaatama, jälgima, tajuma, tähele panema jne (EKG II: 283).

Kui võrrelda väljendeid juhtus, et $x$; ta nägi, et $x$ ja ta kujutles/arvas / mõtles, et $x$, siis esimesel juhul on $x$-i eeldatav reaalsus kõige suurem ja viimasel juhul kõige väiksem. Esimeses väljendis esitatakse $x$-i objektiivse reaalsusena, seevastu viimasel puhul võib $x$ eksisteerida kõigest kõnealuse isiku arus. Tajuverbid jäävad kusagile selle skaala keskele. Ühelt poolt eeldatakse, et $x$ on midagi väljaspool tajujat. Teisalt on tajuakti tähtis osa ka see, kuidas tajuja mingeid välisstiimuleid töötleb. Mitmel põhjusel võib rõhk asetuda vaadeldavatelt nähtustelt ümber vaimsele kujutlusele.

Sedalaadi erinevused võivadki põhjustada eri tüüpi komplementlausetes absoluutse ja relatiivse tempuse ebavõrdse jaotuse. Nende erinevuste seletuseks sõnastab Barentsen Wiedemanniga sarnase hüpoteesi, et sekundaarse orientatsioonipunktina toimimiseks peab teatav ajaperiood ja selles toimuv sündmus seostuma pealauses viidatud kõneleja, vaatleja ehk „pealauseisiku” tunnetusaktiga (Barentsen 1996: 22). Nõnda on ka arusaadav, miks „eksistentsiaalset" tüüpi pealause järel ei ole relatiivne tempus võimalik - pealauses ju mingit isikut pole.

Relatiivse ja absoluutse tempuse jaotus pärast muid verbe paistab aga sõltuvat sellest, kellele on kõrvallause sündmus ligipääsetavam - millisel isikul on sündmusest selgem või täielikum ülevaade: kas pealauseisikul või terviklause esitajal („refereerijal”). Kuna kaudkõne puhul on kõrvallauses mainitud sündmuse peamine infoallikas pealauseisik, siis on siin relatiivne tempus peaaegu ainuvõimalik. Et aga „eksistentsilausetes” pealauseisik üldse puudub, siis on neis ainuvõimalik absoluutne tempus. Ülejäänud verbide puhul on varieerumine seletatav sellega, kui kerge või raske on vaatepunkti vahetada, st nihkuda terviklause kõneleja orientatsioonipunktist pealauseisiku orientatsioonipunkti. (Barentsen 1996: 22)

\section{Et ja kuidas}

Pealause sündmuse ja kõrvallause sündmuse ajalise vahekorra seisukohalt torkavad silma mõned tajuverbide semantilised eripärad. Tajuakt eeldab millegi tajutava kohalolekut, st samaaegsusmomenti. Tajutava sündmuse ajavahemik võib ka üleni mahtuda sellega seostuva tajuakti ajavahemikku. Paistab, et neil juhtudel eelistatakse sidendit kuidas sidendile et ning esimesel juhul jääb kõrvallause sagedamini absoluutsesse tempusesse (s.o minevikku). Vene keele sama tendentsi seletab Barentsen asjaoluga, et sidend как kannab vahetu taju tähendust, markeerimata ja laiemalt kasutatav чmo aga kätkeb ka võimalust, et kõrvallause sündmust ei tajuta otse, vaid järeldatakse kaudselt (1996: 24).

(53) Mari nägi, kuidas lapsed mängisid/mängivad kroketit.

(54) Mari nägi, et lapsed mängivad/mängisid kroketit.

Kahe lause tähenduse erinevus näib seisnevat selles, et esimesel juhul tajuti laste mängu otse ja vahetult, teisel juhul võis see olla ka mingite märkide põhjal tehtud kaudne järeldus või tõlgendus. Väljend nägi, kuidas 
lapsed mängisid on enam-vähem ekvivalentne infinitiivse konstruktsiooniga nägi lapsi mängimas / mängivat (vt Erelt 2014: 192). Et-lause puhul ei tarvitse sündmus - kroketi mängimine - tajuaktis vahetult kohal ollagi, vaid võib järelduda kaudsete vihjete põhjal - vedelevatest kurikatest ja pallidest vms. Olevik et-kõrvallauses viitab tajutud olukorra või sündmuse tõlgenduslikkusele ja sündmust esitatakse sel juhul samaaegsena sekundaarset orientatsioonipunkti pakkuva tajuaktiga: sündmust nähakse pealauseisiku kaudu.

Barentsen kirjeldab kahe sidendi eristust nii: $\kappa$ к eeldab, et kõrvallauses märgitud olukord ei ole staatiline seisund ning et see mahub üleni tajuakti ajavahemikku. Sidend umo lubab tajuakti ja kõrvallause sündmuse kaudsemat suhet; tegelikult tajutu võib olla üksnes vihje, mis viib mõtte osutatud olukorrale. Vene keeles käib koos чmo'ga pigem verbi perfektiivne ja как'iga imperfektiivne aspekt (Barentsen 1996: 26).

Eesti et on samuti laiema tähendusega kui kuidas: kuidas seostub mingi dünaamilise olukorra otsese tajumisega, et seostub tajuakti tõlgenduslikkusega, välistamata siiski võimalust, et sündmus on ka tegelikult kohalolev. Sõnaga kuidas kaasnevast vahetust tajust järeldub sündmuse objektiivne iseloom, mistõttu sündmus ei ole tajutav üksnes sekundaarsest orientatsioonipunktist, pealauseisiku seisukohalt, vaid ka kesksest orientatsioonipunktist, terviklause kõneleja seisukohalt (vt ka Barentsen 1996: 39). Sellega võiks olla seletatav kuidas-kõrvallausetes märksa sagedasem absoluutne aeg (s.o minevik).

\section{Pisut statistikat}

Otsisin etTenTen'i korpusest lauseid, milles lihtminevikulisele tajuverbile nägema, kuulma, tundma, märkama järgneb vahetult sidend et või kuidas, ning leidsin minevikulisi kõrvallauseid 155 korral (verbiga nägema 80, kuulma 25, tundma 45, märkama 5). Neist 43 korral esines sidend et (vastavalt: nägema 29, kuulma 5, tundma 5, märkama 4) ja 112 korral kuidas (nägema 51, kuulma 20, tundma 40, märkama 1). Olevikulisi kõrvallauseid oli 163 korral (pärast verbi nägema 78, kuulma 27, tundma 42, märkama 16), neist 115 juhul esines sidend et (nägema 54, kuulma 20, tundma 27, märkama 14) ja 48 korral kuidas (nägema 24, kuulma 7, tundma 15, märkama 2). Päringu tulemused on koondatud joonisele 1.

Niisiis jaotuvad selles valimis kõrvallausete minevik ja olevik ning et-ja kuidas-laused enam-vähem pooleks (vastavalt 155 ja 163 ning 158 ja 160) ning huvitaval kombel on kuidas'il peaaegu sama suur ülekaal minevikulistes kõrvallausetes (72 \%) kui et'il olevikulistes (70,5\%). Allpool on etTenTen'i materjalist üks näitelause (55-58) iga tüübi kohta (et + minevik, kuidas + minevik, et + olevik, kuidas + olevik):

${ }^{8}$ Barentseni korpusestatistika järgi (mis lisaks tempusele eristab nii pea- kui ka kõrvallauseverbide aspekti) on kõrvallause minevikus 294 korral (видеть, увидеть 145; сльишать, усльгшать 51; чувствовать, почувствовать 41; замечать, заметить 57), neist sidend что esines 119 (51, 9, 27, 32) ја как $175(94,42,14,25)$ korral. Kõrvallause on olevikus 341 korral, millest что esines 285 korral $(132,9,83,61)$ ја как 56 korral $(31,10,14,1)$ (Barentsen 1996: 30). 
(55) Ta tundis, et pinge hakkas juba järgi andma.

(56) Väike poiss kuulis, kuidas tema vanemad vaidlesid vihaselt.

(57) Olid paar päeva reisil olnud ja Ursula nägi, et meri muutub väga tumedaks ja tuleb torm.

(58) Mõrvatu abikaasat hämmastas siinjuures asjaolu, et valvemiilits nägi, kuidas kolm tema purjus kolleegi tassivad jaoskonda muserdatud inimest, ning tal ei tekkinud kahtlustki asja õiguspärasuses.

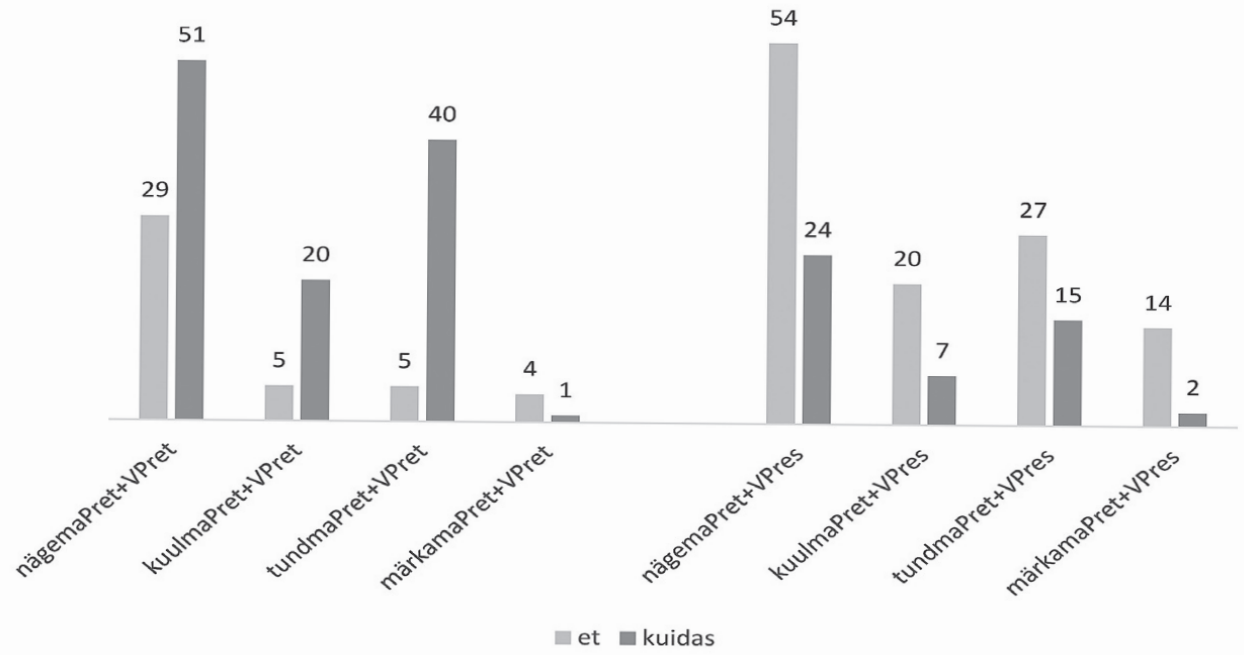

J o o n is 1. Preteeritumi ja preesensi jaotus preteeritumis pealausega komplementlausetes pärast sidendeid et ja kuidas etTenTen’i korpuses.

Kui otsida nendesamade tajuverbidega komplementlauseid A. H. Tammsaare „Kõrboja peremehest” ning „Tõe ja õiguse” esimesest kolmest köitest, leiame, et lihtminevikulise nägema, kuulma, tundma ja märkama järel on komplementlause minevikus 57 korral: 34 korral pärast et'i (nägema 19, kuulma 2, tundma 11, märkama 2) ja 23 korral pärast kuidas't (nägema 12, kuulma 4, tundma 7), ning olevikus 110 korral: 107 korral pärast et'i (nägema 32, kuulma 7, tundma 57, märkama 11) ja ainult 3 korral pärast kuidas't. Olgu siin samuti antud üks näitelause igast võimalusest:

(59) Kõik nägid, kes seisid jaanitule ümber, et Kõrboja perenaine ise andis Katku Villule kätt, ja kõik kuulsid, et perenaine nimetas Villut oma vanaks tuttavaks. (Kõrboja peremees, 8. ptk)

(60 Kristi tundis, kuis ta veri tõusis näkku ja silmis lõi virvendama, nagu langeks kõigile äkki tihe udu. (Tõde ja õigus, III, 23. ptk)

(61) Aga natukese aja pärast kuulsid mehed, et naine, kes kõndis nende kannul, nutab jällegi. (Tõde ja õigus, III, 19. ptk)

(62) Lõpuks olid nad ometi mõlemad, Indrek kui ka Kristi, üsna rahul, sest nad nägid ise oma silmadega, kuidas ka nemad aitavad revolutsiooni süvendada, üldist vabadust kätte võita. (Tõde ja õigus, III, 9. ptk) 


\section{Veel oletusi}

Erinevused eri verbidele alluvate kõrvallausete ajas võivad olla seotud semantiliste erinevustega eri liiki tajusid märkivate verbide vahel. Võiks oletada, et komplementlause minevikku mõjutab ka pealause verbi faktiivsuse määr see, kui tugevasti kannab verb kõrvallause sündmuse tegelikkuse eeldust. Kõne refereerija ei seo end enamasti eeldusega refereeritud väite paikapidavuse kohta, ning võib-olla ka seetõttu jääb kõrvallause verb relatiivsesse aega (s.o olevikku). Seevastu tajulause puhul võib vastutus komplementlauses öeldu eest jaguneda terviklause esitaja ja pealauseisiku vahel. Midagi nähes ja kuuldes (erinevalt millegi teadmisest või mõistmisest) võidakse siiski ka eksida, mõnikord nähakse ja kuuldakse hallutsinatsioone ja viirastusi. Kui mööndakse taju subjektiivsust, kasutatakse pigem olevikku. (Verbiga nägema seostub arvatavasti suurem tõlgenduslikkus kui verbiga kuulma. On ju sellel ka lisatähendus 'aru saama', millisel juhul see toimib pigem verbum cogitandi või sciendi'na kui sentiendi'na. Samas antakse verbiga kuulma peale aistingute ja tajude edasi ka vahendatud infot, millisel juhul kuuluvad vastavad komplekslaused juba kaudkõne lähedusse.) Märksa suuremaid komplementlausete korpusi läbi sõeludes annaks võib-olla koostada mingisuguse tajuverbide faktiivsuse skaala vastavalt sellele, kui sageli käib kõrvallauses nendega kaasas relatiivne tempus.

Kõrvallause ajavormi peamine mõjutaja on see, kas sealset sündmust esitatakse kesksest orientatsioonipunktist (kõnehetkest) või pealauseisiku sekundaarsest orientatsioonipunktist. Sekundaarse orientatsioonipunkti olemasolu ei kaota aga keskse orientatsioonipunkti tähtsust. Paljudel juhtudel mõjutab tempuse valikut ka see, kas sekundaarsel orientatsioonihetkel eksisteeriv sündmus või olukord kestab edasi ka keskses orientatsioonipunktis, terviklause lausumisajal (nagu näidetes 20, 30, 31 või joonealuses 4). Niisiis võib kõrvallause olevik olla tingitud mainitud sündmuse samaaegsusest nii pealauseisiku orientatsioonipunktiga kui ka keskse ehk terviklause kõneleja orientatsioonipunktiga. Viimasel juhul on tegu habituaalse olevikuga või ajatu olevikuga.

Barentsen toob esile veel mõned kõrvallause minevikku tingivad tegurid, mis toetavad kõik üldist hüpoteesi, et neil juhtudel on kõrvallauses mainitud sündmus või olukord kesksest orientatsioonipunktist suhteliselt ligipääsetavam kui sekundaarsest orientatsioonipunktist.

Neid tähelepanekuid eesti keelele kohaldades võib oletada, et lisaks sidendile kuidas võib komplementlause minevikku soodustada veel:

1. Eitus pealauses:

(63) Mari ei näinud, et Jüri leidis rahakoti.

2. Täissihitisega väljendatav kõrvallause perfektiivsus (osasihitis esineb niikuinii enamasti koos sidendiga kuidas):

(64) Mari nägi, et Jüri pühib pisaraid.

(65) Mari nägi, et Jüri pühkis pisarad. 


\section{Järjestikused tegevused:}

(66) Jüri nägi, et Mari ostis jäätise, võttis selle paberist ja hakkas sööma.

4. Korduvad tajuaktid (juhtumid, milles tajuakt teadvustab olukorda, mis on juba mõnda aega kestnud ja jätkub pärast tajuakti lõppu):

(67) Kuulsin veel mitu korda, et Jüri hü̈̈dis appi.

5. Vahendatud informatsioon:

(68) Jüri sõnul tundis Mari vaistlikult, et Jaan oli ta selja taga.

6. Pealause impersonaalsus laias mõttes, nt nn anonüümne „avalik arvamus" näidetes 59 ja 69:

(69) Ükski ei osanud arvata, miks ta ei saa, aga kõik nägid, et ta oli aina üksinda, ja kõik arvasid, et olgugi preili, ometi on ta nii-öelda naisterahvas, ja mis kohapidaja on naisterahvas, liiatigi kui koht on niisugune, nagu on Kõrboja. (Kõrboja peremees, 6. ptk) ${ }^{9}$

Samas ei saa päris kindel olla, kas kõik need tegurid toimivad eesti keeles sarnaselt vene keelega. Ülal konstrueeritud näitelausetes 63-68 tunduvad ajad vabalt vahetatavad ning mitmel pool näib loomulikumana hoopis kombinatsioon kuidas + olevik.

\section{Ajasuhted narratiivses ja retrospektiivses režiimis}

Lisaks eelmises peatükis mainitud teguritele, mis on väga oletuslikku laadi ja vajavad korpuste põhjal kontrollimist, tuleks Barentseni järgides mainida üht veelgi ähmasemat tegurit - seda, kas tekst kuulub retrospektiivsesse või narratiivsesse režiimi.

Kahe „lausumistasandi”, loo (pr histoire) ja kõne (pr discours) vahelisele eristusele juhtis esmakordselt tähelepanu Émile Benveniste (1971 [1959]) seoses minevikuaegade tarvitamisega prantsuse keeles: loo jutustamise korral kasutatakse aoristi prantsuse ekvivalenti ehk lihtminevikku, passé simple'it, vahetus suhtlemises on käibel perfekt ehk liitminevik (passé composé). Viimane loob minevikusündmuse ja oleviku vahele elava seose, samas kui puhtakujulises loojutustuses kõneleja justkui puuduks: sündmusi esitatakse kronoloogiliselt, nende toimumise järjekorras. „Keegi siin ei kõnele, sündmused näivad jutustavat end ise" (Benveniste 1971 [1959]: 208). Aorist või passé simple on aeg, mis kuulub kokku jutustajaisikuväliste sündmustega.

Kuigi kahe lausumistasandi (või õigupoolest kahe eri jutustamisviisi) niisugusele vastandusele enamikus keeltes otsest grammatilist ekvivalenti pole, on Benveniste'i eristus leidnud mitmel korral ülesvõtmist ja edasiarendamist (vt Fludernik 2012; Padutševa 2011; Paducheva 2011; Benveniste'ist juba varem

${ }^{9}$ Siin näites ilmneb selge kontrast minevikku tingiva verbum sentiendi (nägid) ja olevikku tingiva verbum cognoscendi (arvasid) vahel. 
ja sõltumatult Hamburger 1993 [1957]). Sellele poolele, kus Benveniste'il on kõne (pr discours), jääb Jelena Padutševal „kanooniline kommunikatsioon” ehk kõnerežiim (Paducheva 2011: 116-117, 137; Padutševa 2011: 13, 287), Barentsenil „retrospektiivne režiim” (Barentsen 1996: 36) ja Hamburgeril „tegelikkuseütlused” (sks Wirklichkeitsaussagen). Teisele poole jääb aga kõigil „narratiivne” režiim, laad või tasand. Kanoonilise kommunikatsiooniga, retrospektiivse laadiga, kõnerežiimiga, diskursuse plaaniga on tegu siis, kui jutustatakse kõnelemisaja seisukohalt tagasi vaadates, pealtnägijast tunnistajana, kes meenutab n-ö eest tahapoole, olevikust minevikku sirutudes, et sealt mingit informatsiooni välja kaevata ja oma adressaatide ette laotada. Sel juhul hinnatakse minevikusündmusi hilisemalt, kõnehetke seisukohalt. Puhta jutustamisega, looga, narratiiviga on tegu siis, kui tekst kulgeb edasi justkui loo sündmustega käsikäes, ilma et jutustaja-oleviku vaatepunkt kuidagi sündmuste edasiandmisse sekkuks. Sel juhul on esiplaanil sündmuste kui terviku osade omavahelised seosed ja mitte nende seos kõnelejaga.

Eesti keeles selgeid vormilisi vasteid sellele eristusele ei ole. Aga kui kunagisi tajuakte käsitletakse retrospektiivses režiimis, nüüdisaja seisukohalt ja tagasivaateliselt, ning mitte nende omaaegse tähenduse ja tähtsuse perspektiivist looterviku osadena, siis peaks esile tõusma keskse vaatepunkti tähtsus. See peaks omakorda tooma kõrvallausetesse absoluutse aja - nii nagu ka juhtudel, kus tajuakt esineb kellegi teise raportis (vt näidet 68).

Võib-olla tulevad režiimierinevused selgemini esile pigem ajadeiktikute kui tempuste kasutuses. Ajavahemikele, mida retrospektiivses režiimis tähistatakse pigem relatiivsete ajadeiktikutega eelmisel/samal/järgmisel päeval, viidatakse narratiivses režiimis tegelaskeskselt, deiktikutega eile, täna, homme. Käte Hamburger nimetab fiktsionaalsetes jutustustes esinevat minevikutempust „eepiliseks preteeritumiks” (Hamburger 1993 [1957]: 64-98). See on mittedeiktiline ehk kõnehetkest lahtiseotud tempus, mis ei tähista mingisugust reaalset aega ega osuta sündmuste ja olukordade kuuluvusele mõnda möödunud ajaperioodi, vaid ainult nende fiktsionaalsusele. Eepilise preteeritumi põhitunnuseks on minevikutempuse kasutamine koos sama- ja lähiaegsust (täna, nü̈̈d) või tulevikulisust (homme, varsti) tähistava ajadeiktikuga. Hamburgeri järgi on ainult fiktsionaalses narratiivis võimalikud sellised laused ${ }^{10}$ :

(70) Jaapanlannad olid õnnetud, kriimud, homme oli neil esinemine. (Arvo Valton, Kaheksa jaapanlannat. - A. Valton, Mustamäe armastus. Tallinn: Eesti Raamat, 1978, lk 67)

(71) Oli pühapäeva õhtu ja õhtusöögiks tulid nad kõik koju, sest homme oli jälle tööpäev, mis algas päikesetõusuga. (Karl Ristikivi, Lohe hambad. Lund: Eesti Kirjanike Kooperatiiv, 1970, lk 125)

Guugeldamine näitab siiski, et fraase Homme oli tööpäev; Ta ärkas rõómuga. Täna oli ilus ilm; Nü̈̈d oli ta väsinud jne, milles ajamääruste tähendus ei lähtu kõnehetkest, vaid mingist sekundaarsest tekstisisesest orientatsioonipunktist, esineb vähemalt eesti keeles kõikvõimalikes tekstides, mitte üksnes

${ }^{10}$ Hamburgeri enda musternäide on Alice Berendi romaanist „Die Bräutigame der Babette Bomberling” (1915): „Aber am Vormittag hatte sie den Baum zu putzen. Morgen war Weihnachten.” ('Kuid ennelõunal pidi ta ehtima kuuske. Homme olid jõulud.') 
ilukirjanduses. Tundub, et erinevalt inglise, saksa jm keeltest ei käitu eile, täna, homme eesti keeles sugugi alati absoluutsete ajadeiktikutena, mille ankur ehk lähtepunkt on kõnehetkes, vaid need võivad ka väljaspool ilukirjandust esineda sageli relatiivsete deiktikutena mingist sekundaarsest orientatsioonipunktist: lausetes, kus inglise keeles oleksid ainuvõimalikud the day before, the same day ja the day after.

(72) Homme oli aga nii, et VARAhommikul perearsti kojukutse tellimisel tuli öelda, et kahjuks tuleb tulla täna juba surma fikseerima. (etTenTen)

(73) Nagu mustaga valgel kirjas, ilmusin 1951. aasta teise veebruari hommikul velskripunkti, kuid see oli kinni. Nägin veel lahkuvat kütjat, kes ütles, et täna siia ruumidesse enam keegi ei tule.

(74) Ja sündis, kui nad ühel sobival päeval varitsesid, et naine läks sinna nagu eile ja üleeile, kaasas ainult kaks tüdrukut, ja tahtis rohuaias ennast pesta, sest oli palav. ( $\mathrm{Su} \mathrm{1:15)}$

(75) Kutt läkski, ja tüdruku ema tuleb vastu, on hästi kurva näoga. Poiss vaatab: „Mis on?” See ema küsis, et kas sa ei tea sellest või midagi niisugust. Poiss ütles, et mina ei tea midagi, et ma tahan tüdrukuga kokku saada. Naine ütles, et tüdruk on ju kaks kuud juba surnud. Kutt ütles, et mine nüüd, et me olime taga eile terve öö baaris, et ma võtsin ta vöögi veel oma kätte ja et baaris võivad kõik tunnistada. (http://www.folklore.ee/rl/ pubte/ee/cf/mjap/eda.html)

Retrospektiivse ja narratiivse režiimi vahe ehk kesksest ja sekundaarsest orientatsioonipunktist jutustamise erinevus langeb kokku erinevusega selles, kas sündmusi esitatakse terviklause kõneleja seisukohast, kasutades absoluutset tempust ning ajadeiktikuid eile, täna, homme absoluutsena, või pealauseisiku seisukohast, kasutades relatiivset tempust ja neidsamu ajadeiktikuid relatiivsena. See erinevus on omakorda paralleelne jutustaja ja tegelase vaatepunkti või teksti erinevusega (vt tabelit 1).

Tabel 1 .

\section{Vastavused möödunud sündmuste esitamise kahe laadi vahel}

\begin{tabular}{|c|c|}
\hline retrospektiivne režiim & narratiivne režiim \\
\hline $\begin{array}{c}\text { keskne orientatsioonipunkt } \\
\text { kõnehetkes }\end{array}$ & $\begin{array}{c}\text { tekstisisene sekundaarne } \\
\text { orientatsioonipunkt }\end{array}$ \\
\hline terviklause kõneleja vaatepunkt & pealauseisiku vaatepunkt \\
\hline $\begin{array}{c}\text { absoluutne tempus } \\
\text { komplementlausetes }\end{array}$ & $\begin{array}{c}\text { relatiivne tempus } \\
\text { komplementlausetes }\end{array}$ \\
\hline $\begin{array}{c}\text { eile, täna, homme absoluutsete } \\
\text { deiktikutena }\end{array}$ & $\begin{array}{c}\text { eile, täna, homme relatiivsete } \\
\text { deiktikutena }\end{array}$ \\
\hline jutustajateksti domineerimine & $\begin{array}{c}\text { jutustajateksti ja tegelasteksti } \\
\text { põimumine }\end{array}$ \\
\hline
\end{tabular}

Niimoodi kirjeldatud narratiivse ja retrospektiivse laadi eristus ei kattu päriselt Benveniste'i ega ka Hamburgeri pruugiga, kes mõlemad rõhutavad narratiivse režiimi umbisikulisust ja kõnelejainstantsi varjujäämist selles 
ning välistavad narratiivsusest esimese isiku. Benveniste ütleb: „(Aja)loolise lausungina me defineerime minevikusündmustest jutustamist, mis välistab kõik „autobiograafilised” keelendid” (Benveniste 1971 [1959]: 206). Viimaste hulka arvab ta mina, sina, siin ja nü̈̈d. Aga Padutševa ja Barentseni poolt teisendatud pruugis viitaksid narratiivsele režiimile just nimelt sellised deiktikud, kui neid kasutatakse sekundaarsest orientatsioonipunktist ehk pealauseisikute ehk jututegelaste tekstisisesest perspektiivist.

Narratiivse laadi olemus on loo osade jutustamine sündmuste tegelikku kronoloogilist järjestust enam-vähem peegeldavas järjekorras. Selles laadis on esmatähtsad tegevuste-/sündmustevahelised suhted, kuid nende suhe keskse orientatsioonipunktiga (jutustamishetkega) on kõrvaline. Lugu jälgides on kerge omaks võtta mõne selle osalise vaatepunkt, nii nagu seda tehakse ka komplementlausete puhul, mis esitavad kellegi mõtteid, uskumusi ja tajusid.

\section{Järeldused}

Artikkel vaatles ajakasutust komplementlausetes üldiselt ja konkreetsemalt tajuverbidele alluvates kõrvallausetes ning otsis eesti materjalist kinnitust Adrian Barentseni (1996) vene keele kohta tehtud tähelepanekutele. Kõrvallause aegade varieerumine on seletatav sellega, et pealause verbi aeg ja kõrvallause verbi aeg on määratletavad eri orientatsioonipunktidega. Pealause verbi aega orienteerib enamasti kõnehetk, kõrvallause aega võib aga orienteerida ka pealauses mainitud sündmus või olukord.

Viimane võimalus ehk relatiivne tempus esineb eri tüüpi komplementlausetes eri sagedusega. Pealause annab sekundaarse orientatsioonipunkti siis, kui selles osutatakse mingi isiku vaimuaktile. See, kas kõrvallause sündmust vaadeldakse pealauseisiku silmadega (tema vaatepunktist) või terviklause kõneleja silmadega, sõltub sellest, kummale on kõrvallause sündmus ligipääsetavam. Seetõttu on relatiivne aeg normiks kaudkõnes, samal ajal kui tajuverbide järel on üsna tavaline ka absoluutne aeg. Lisaks sõltub aja valik sidendist: kuidas toob et'ist sagedamini kaasa absoluutse aja, sest kannab objektiivse „vahetu tajumise” tähendust, samal ajal kui pärast et’i mainitud sündmus võib olla pealauseisiku subjektiivne järeldus või tõlgendus.

Püüdsin komplementlause relatiivse ja absoluutse aja (s.o oleviku ja mineviku) esinemissagedust oletuslikult seostada ka muude teguritega, muuhulgas sellega, kas lauset saab võtta narratiivsesse või retrospektiivsesse režiimi kuuluvana. Puudutasin põgusalt ajadeiktikute käitumist neis režiimides ning spekuleerisin võimalusega, et sekundaarne vaatepunkt (tekstisisene deiktiline nullpunkt) iseloomustab pigem narratiivset ning keskne vaatepunkt retrospektiivset režiimi.

Neist tähelepanekuist võiks olla abi nendele, kes tõlgivad aegade ühildumisega keeltest, sest puudutasin juhtumeid, kus absoluutse aja säilitamine kõrvallauses poleks õige ning kus selle asemel võiks või tuleks kasutada relatiivset aega.

See, kui palju orientatsioonipunktide varieeruvusest rahvavaimu kohta järeldub, jäägu metsikuma lingvistika arutada. Arutluste lähtepunktiks võiks sobida üks Jaan Kaplinski meenutus Uku Masingust: „Temas oli mingi vimm lõunaeestlaste vastu ja põhjaeesti patriotism. Ta leidis näiteks, et lõunaeest- 
lased on egotsentrilised vms. Nemad ei ütle „Ma tulen sinu poole”, vaid „Ma lähen sinu poole" - lähtepunktiks võetakse rääkija, mitte see, kelle poole minnakse." (Kaplinski 2012: 80)

Kokkuvõtteks võib Wiedemanni sissevaadet edasi arendades öelda, et komplementlause tempus sõltub nii ajast kui ka arust: nii kõrvallause sündmuse toimumisajast kui ka sellest, kelle arust see sündmus toimub, kas terviklause kõneleja arust või pealauseisiku arust.

\section{Kirjandus}

A u e r b a ch, Erich 1965 [1958]. Introduction: Purpose and method. - E. Auerbach, Literary Language and Its Public in Late Antiquity and in the Middle Ages. Tlk Ralph Mannheim. London: Routledge and Kegan Paul, lk 5-24.

Barentsen, Adrian 1996. Shifting points of orientation in modern Russian: Tense selection in 'reported perception'. - Reported Speech: Forms and Functions of the Verb. Toim Theo A. J. M. Janssen, Wim van der Wurff. AmsterdamPhiladelphia: John Benjamins.

Benveniste, Émile 1971 [1959]. The correlations of tense in the French verb. - E. Benveniste, Problems of General Linguistics. Tlk Mary Elizabeth Meek. Coral Gables: University of Miami Press, lk 205-215.

EKG I = Mati Erelt, Kaja Tael, Silvi Vare, Eesti keele grammatika I. Morfoloogia. Sõnamoodustus. Tallinn: Eesti Teaduste Akadeemia Eesti Keele Instituut, 1995. EKG II = Mati Erelt, Reet Kasik, Helle Metslang, Henno Rajandi, Kristiina Ross, Henn Saari, Kaja Tael, Silvi Vare, Eesti keele grammatika II. Süntaks. Lisa: Kiri. Tallinn: Eesti Teaduste Akadeemia Keele ja Kirjanduse Instituut, 1993.

Erelt, Mati 2013. Eesti keele lauseõpetus. Sissejuhatus. Öeldis. Tartu: Tartu Ülikooli eesti keele osakond.

Erelt, Mati 2014. Eesti keele lauseõpetus. Komplekslause. Tartu: Tartu Ülikooli eesti keele osakond.

Fludernik, Monika 2012. Narratology and Literary Linguistics. - The Oxford Handbook of Tense and Aspect. Toim Robert I. Binnick. Oxford: Oxford University Press, lk 75-101.

H a m b u r g e r, Käte 1993 [1957]. Logic of Literature. Tlk Marylin J. Rose. 2nd rev. edition. Bloomington: Indiana University Press.

Ka plins ki, Jaan 2012. Ütles Masing. - Vikerkaar, nr 1-2, lk 74-98.

Le e c h, Geoffrey, Sh ort, Michael 1981. Style in Fiction: A Linguistic Introduction to English Fictional Prose. London: Longman.

M c H a le, Brian 1978. Free indirect discourse: A survey of recent accounts. - PTL: A Journal for Descriptive Poetics and Theory of Literature, nr 3, 249-278.

P a d u t š ev a 2011 = Е. В. Падучева, Семантические исследования. Семантика времени и вида в русском языке. Семантика нарратива. Изд. 2-е. Москва: Языки славянской культуры.

Paducheva, Elena 2011. The Linguistics of Narrative. The Case of Russian. Moscow: Lambert Academic Publishing.

S e r e bren nik ov 1963 = Б. Серебренников, Категории времени в прибалтийско-финских языках. - Eesti keele süntaksi küsimusi. Tallinn: Eesti NSV Teaduste Akadeemia Keele ja Kirjanduse Instituut, lk 426-515.

Tauli, Valter 1980. Eesti grammatika II. Lauseõpetus. Uppsala: Almquist \& Wiksell. 
Wi ed e mann, Ferdinand Johann 2011 [1875]. Eesti keele grammatika. Tlk ja eessõna Heli Laanekask. Tallinn: Eesti Teaduste Akadeemia Emakeele Selts.

Yli-Vakkuri, Valma 1994. Tempuksenkäyttö suomalaisessa ja virolaisessa fiktiivisessä tekstissä. - Lähivõrdlusi. Lähivertailuja 7. Toim Karl Pajusalu, Valma Yli-Vakkuri. Turku: Turun yliopisto, lk 136-149.

\section{On tense and consciousness: Tense and the centre of orientation in Esto- nian complement clauses}

Keywords: complement clauses, sequence of tenses, indirect speech, indirect perception, discourse vs. narrative, deictic points of orientation, absolute and relative tense, translation theory

Testing Adrian Barentsen's insights regarding tense in Russian complement sentences on Estonian material, the article examines the use of the present and preterite tenses in Estonian complement clauses if the main clause verb is in the preterite. The starting point is the well-known observation that some languages show a shift in verb tense (sequence of tenses) in indirect speech, while some others do not. Estonian, while not having tense shift in indirect speech, has it in sentences embedded under "existential” verbs like juhtus or sündis 'happened, occurred'. Verbs of perception allow for both the shift (i.e. absolute tense) and nonshift (i.e. relative tense). Similarly with Russian, in Estonian the most relevant factor accounting for the difference is the accessibility of the points of orientation of the embedding clause and the embedded clause, depending on whether the event described in the complement clause is presented as an objective fact or as an interpretation by the main clause person. In the former case, absolute tense, i.e. the preterite, prevails, while in the latter case, relative tense, the present, is more common. The conjunction et 'that' tends to favour the relative tense, while kuidas 'how' brings about more often the absolute tense. Some conjectures regarding the distinction between the narrative and retrospective modes of utterance are entertained as a possible further explanation for the differences in the distribution of tenses and temporal deictics such as eile 'yesterday', täna 'today', homme 'tomorrow' on the one hand, and eelmisel päeval 'the day before', samal päeval 'that day', järgmisel päeval 'the next day' on the other. Awareness of the factors inf luencing tense selection for complement clauses in languages without tense shift could have a practical relevance for translating from languages with a sequence of tenses (Finnish, Swedish, English, French, etc).

Märt Väljataga (b. 1965), Tallinn University, Lecturer of Literary Theory, martval@ tlu.ee 